\title{
Commodity Price Changes and Domestic Inflation in the CEMAC Zone: Evidence from Panel Cointegration
}

\author{
Njoupouognigni Moussa ${ }^{1} \&$ Ndambendia Houdou ${ }^{1}$ \\ ${ }^{1}$ Ecole Normale Supérieure d'Enseignement Technique, University of Douala, Cameroon \\ Correspondence Njoupouognigni Moussa, Ecole Normale Supérieure d'Enseignement Technique, University of \\ Douala, Cameroon. Tel: 237-699-883-034. E-mail: mnjoupouognigni@ yahoo.fr
}

Received: August 22, 2020

Accepted: April 10, 2021

Online Published: April 25, 2021

doi:10.5539/ijef.v13n5p93

URL: https://doi.org/10.5539/ijef.v13n5p93

\begin{abstract}
In this study, we highlight the issue of the recent rise of food prices and other commodities on domestic inflation in the CEMAC zone. Results show that there is a long-run relationship between consumer price index, commodity prices and traditional determinants of inflation. Indeed, an appreciation of the nominal effective exchange rate and a rise of interest rate reduce domestic inflation while excessive money supply and a surge of commodity prices are potential sources of inflation in the region. Moreover, Pass-through from commodity price changes to domestic inflation in the region is incomplete because of the CFA Franc peg to Euro. An efficient use of the tools of monetary policy and a coordinated food policy on crops are more likely to reduce inflationary pressures in the region.
\end{abstract}

Keywords: commodity prices, consumer price index, cointegration, CEMAC zone

JEL classification: C01, E31, Q02.

\section{Introduction}

The recent food crisis has been particularly characterized by the general increase of the consumer price index around in the world, especially in developing economies, shows how important is an external shock of the price level on these countries, including countries in CEMAC zone. Indeed, the general price level by definition takes into account in the reference basket a number of products which are particularly imported for direct consumption such as rice or used as inputs to produce some food items such as wheat for bread or maize for beverage. Exogenous shocks due to climate change with the outcome of poor harvests or the financialization of commodities may particularly contribute to a high volatility of the prices of these raw materials that will undoubtedly have a devastating effect on the economies of developing countries. These countries spend in general more than half of their income on consumer goods with foods representing an important part of the basket of reference for the calculation of the price index (CPI).

The recent surge in food prices, coupled with a sustained increase in oil prices due to ever increasing demand from emerging economies has particularly affected developing economies. Indeed, inflation in sub-Saharan Africa has reached the level of $11.7 \%$ and $10.5 \%$ in 2008 and 2009, respectively. The CFA Franc zone which operates under a fixed exchange rate regime is made up by two monetary unions: the WAEMU and CEMAC (Note 1) has experienced average inflation rate of $7.1 \%$ in 2008 and $2.1 \%$ in 2009. CEMAC zone, which is the subject of this study, has experienced an average inflation rate of $5.7 \%$ in 2008 and $4.7 \%$ in 2009, compared to $2.8 \%$ on average over the period 2004-2008. However, inflation in CEMAC has remained relatively stable after the introduction of the Euro to the recent surge in commodity prices which reached a record level of $23.3 \%$ in 2008. In view of these statistics, it is clear that the level of inflation in the CEMAC zone has crossed the implicit target of $3 \%$ as a result of higher commodity prices in 2008 . However, the inflation in the region has not reached a double digit level. The problem to be addressed in this study is whether the inflation level experienced by the region in 2008 was a monetary phenomenon or the result of imported inflation.

Inflation, considered as a variation of the general price level, is often seen as a monetary phenomenon if we borrow the term used by Milton Friedman who said "inflation is always and everywhere a monetary phenomenon". This assertion leads the author to suggest a monetary policy rule based on the monetary aggregate to better control the variation in the general price level. This control of the general price level requires a good 
knowledge about the major determinants, monetary and non-monetary, the consumer price index. With a policy of monetary targeting in the region, monetary determinants of the consumer price index seems to be better controlled unlike non-monetary determinants which are mostly out of reach of monetary authorities. Some determinants of the non-monetary inflation such as the fluctuation of commodity prices on international markets seem to be particularly relevant for the dynamic of the general price in the CEMAC region. This explains the interest of a reflection on the effects of the commodity price changes, especially food and oil, on the dynamic of the general price level in the zone.

The structure of the reference basket for the computation of the consumer price index in the region also explains the choice of this study in a monetary union. Indeed, food imports constitute a significant part of the reference basket of low-income countries. Food items generally represent $45 \%$ of the total items unlike that of developed economies with about $15 \%$ of foods items (IMF, 2012). We suspect the structure of this reference basket not to be different for the countries of the CEMAC zone.

The main objective of this study is to measure the extent of a fluctuation in the prices of raw materials imported into the dynamics of the general price level of the CEMAC zone. The main objective is divided into two secondary objectives. The first is to characterize the importance of different products imports (food, metals and oil) in the dynamics of domestic inflation zone after a decomposition of the overall index into sub-indices food, metals and oil. This decomposition is of great importance since it will identify the sub-index particularly dangerous for the general level of prices, which deserves more attention on the part of monetary authorities to ensure price stability in the monetary area. The second secondary objective is to measure the ability of monetary policy instruments with the objective of price stability.

The main motivation of this study focuses on two aspects: the first is drawn from the characteristics of the economies of the CEMAC zone and the second is about the ongoing debate on oil subsidies in the region. Indeed, the economies of the region are producers and exporters of raw materials. The soaring prices of these contribute to an influx of capital into the financial system and potential source of inflation in the absence of a sterilization policy or low absorption capacity. Similarly, the debate over the removal of oil subsidies to free up resources for a strong and inclusive growth also justifies the interest of this study.

It appears from this study that the overall index of raw materials has a significant influence on the dynamics of the domestic inflation in the CEMAC region. In fact, a $1 \%$ increase in the overall index of raw materials is accompanied by an increase of $0.22 \%$ in the general price level of the zone. Decomposition of the overall index into sub-indices shows that the food sub-index is the most dangerous in the dynamics of the general price level of in the region. A $1 \%$ increases in this sub-index cause an increase in the general price level of $0.19 \%$ in the area. The appreciation of the nominal exchange rate contributes to price stability, as well as the rate of the central bank, but in a small proportion. An increase in the stock of money would marginally increase the general price level in the area.

The rest of the study is presented as follows: the second section present a literature review on the topic. The third section presents a theoretical framework of the study. An empirical evaluation is discussed in the fourth section, while the final section concludes with some policy implications.

\section{Literature Review}

The link between domestic inflation and commodity price is not new in the literature. It has retained the attention economists since the first oil shock in 1973-1974. However, this literature remains strongly dedicated to developed economies with little emphasis on developing countries in general and especially the countries of the CEMAC zone. The existence of a relationship between domestic inflation and commodity price fluctuations is not clear in the literature. Most of the work carried out on the decade 1980-1990 concluded to a weak or inexistent link between domestic inflation and commodity prices (Boughton \& Branson, 1988; Flood, 1989; Krugler, 1991; Adams \& Ichino, 1995; Furlong \& Igenito, 1996; Hobijn, 2008). The second group of works found the positive link between inflation and commodity price changes (Boughton, 1989; Bloomberg \& Harris, 1995; Mahdavi \& Zhou, 1997; Zoli, 2009; Ciner, 2011; Egert, 2011). The price of oil is at the center of this relationship with both domestic inflation (direct effects) and prices of other raw materials (indirect effects).

Fluctuation of non-oil commodity is often seen as a consequence of rising oil prices. Indeed, oil is a major input in the production of fertilizer used in the production of other primary commodities such as cocoa, rice, wheat, etc. Baffes (2007) found a strong correlation between oil prices and those of fertilizers, raw materials, and metals. He concluded for a sustained rise in commodity prices if the price of oil remains high over time. This conclusion is also shared by Nazlioglu and Soytas (2012) with regard to the results of their empirical work on the relationship between oil prices, commodity prices and the U.S. dollar. 
In the context of developing economies, the empirical results on the inflation dynamic and commodity price fluctuations were also mixed. Recent work on the impact of the recent food crisis on domestic inflation in developing economies in Asia show that the rise of prices in 2007-2008 in the region came from internal factors (aggregate demand and inflation expectations) and not external factors such as rising commodity prices (and Jongwanich Park, 2009). Only domestic inflation in Vietnam was created by external shocks such as rising food and oil prices.

Similarly, the sources of the recent surge in prices in the four economies of East Africa (Ethiopia, Kenya, Tanzania and Uganda) have been strong growth of the money supply, domestic credit and monetary financing of fiscal deficit. Commodity food prices accounted only for a small part of the domestic inflation in the region (AFDB, 2011).

In contrast, Al-Eyd et al. (2012) found food prices to be a significant determinant of the domestic inflation in the short term for the four Central Asian countries (Kazakhstan, Tajikistan, Uzbekistan and the Republic of Kyrgyz).

Browne and Cronin (2010) emphasize the importance of the inclusion of the money supply in the analysis of the relationship between commodity prices and domestic inflation. Indeed, in the context of a lax monetary policy, speculation has been deported to non-financial assets, such as raw materials with the consequent of increase in the general price level of goods and services.

Boughton and Branson (1988) found no relationship between cointegration in commodity prices and the prices of manufactured goods. In another study, using a much longer series, Boughton (1989) comes to the conclusion that there is a long-term relationship between the two series.

\section{Theoretical Framework}

In an attempt to explain the sources of inflation in the CEMAC zone focusing on external factors, it is important to review the various theories about potential causes of inflation. We will review Keynesian school, monetarist and structuralist school about the sources of inflation with a particular emphasis on the structuralist view in the case of domestic inflation in the CEMAC region.

In addition to the sources summarized in the various economic thought, economic literature generally holds as sources of domestic inflation fiscal deficit, excess money supply, currency depreciation (Akinboade et al., 2004). In fact, monetary financing of fiscal deficit is often regarded as the channel through which a deficit may create inflation. The excess money supply that is not compatible with aggregate demand is a source of inflation. Therefore, the stability of inflation requires a control of the money stock (Friedman \& Goodhart, 2003, p. 16). Finally, currency depreciation is also a source of inflation through imported inflation. The latter source is always existent in an open economy with a weak currency.

Keynesians consider aggregate demand and supply as a potential source of inflation. Their theory on inflation is best understood through the Philips curve which establishes the link between inflation and unemployment (Philips, 1973). Indeed, Keynesian theory considers a positive relationship between output and the general price level. This positive relationship is due to the convexity of the Phillips curve (Friedman \& Schwartz, 1982).

For monetarists, excess money supply is a source of domestic inflation. Monetarist theory of inflation takes its roots in the thought of classical economists. Indeed, the classical thought start of the quantity theory of money to conclude that excessive money creation is the cause of inflation in an economy. This leads Milton Friedman (1971) to conclude that "inflation is always and everywhere a monetary phenomenon." For monetarists, inflation is the result of rising aggregate demand that is not covered by sufficient supply. This imbalance is the result of an increase in the money supply (LIM, 1987).

For structuralists, inflation is the result of a link between the food bottleneck, income distribution, and social tensions on the wage determination. A modified version, taking into account monetarist view in the model, has been proposed in the literature (Note 2). This modified version is carried out by including food subsidies in the monetarist model that connects prices, public deficit and currency (Agenor \& Montiel, 2008).

\section{Empirical Analysis}

In other to give answer to the central question stated earlier, this section centered to the empirical evaluation will be structured as follows: the first sub-section will focus on data description and computation while the second and the third sub-section deal with econometric model and interpretation of the results.

\subsection{Data Description}

We use monthly data over the period 2000M1-2012M12 to carried out an empirical investigation of the research question of the study. This data come from the following sources: UNcomtrade (United Nations Commodity 
Trade Statistics database) for the imported value oil and non-oil commodities, these values are used to calculate weights assigned to the corresponding indices, IFS (International Financial Statistics) for data on consumer price indices (CPI), broad money supply (M2), nominal effective exchange rate (NEER), WEO (World Economic Outlook) for the commodity prices indices. Countries included in the study are all the member states of the CEMAC zone: Cameroon, Gabon, Equatorial Guinea, Republic of Congo, Chad and Central African Republic. Equatorial Guinea will be excluded from the regression model because of the unavailability of the import values in the database. This exclusion does not affect the quality of results.

\subsection{Computation of Commodity Prices Indices and Nominal Effective Exchange Rate}

The first analysis starts with the computation of an overall index of oil, food and metal products is which calculated as follows for each country:

$$
I G_{i, j}^{t}=\prod_{j=1}^{3}\left(\frac{P_{j}^{t}}{P_{j}^{0}}\right)^{w_{i, j}^{0}}
$$

The second analysis is done with a breakdown of non-oil commodities such as food (maize, rice, wheat, soybeans, sugar), metals (iron and steel, aluminum, copper) and oil commodity (crude or refined oil and gas). The index of each group is constructed as a geometric mean of the index of each product in the basket of commodities selected. The formula is given as follows:

$$
S I G_{i, j}^{t}=\prod_{j=1}^{k}\left(\frac{P_{j}^{t}}{P_{j}^{0}}\right)^{w_{i, j}^{0}}
$$

This formulation is inspired by the work of Deaton and Miller (1995), Dehn (2000). Each sub-index will be named overall SIGF for food products with $k=6$, SIGM for the metal products with $k=3$ and SIGP for the oil price index with $k=2$. The weight of each component in the sub-index is formulated as follows:

$$
w_{i, j}^{0}=\frac{P_{j}^{0} Q_{i, j}^{0}}{\sum_{j=1}^{k} P_{j}^{0} Q_{i, j}^{0}}
$$

$P_{j}^{0}$ is the price of the product $j$ in the basket considered for the base period and $Q_{i, j}^{0}$ is the value of imported product to the reference year. These various indices calculated are used in an econometric model with other traditional determinants of domestic inflation such as broad money supply (M2), nominal effective exchange rate (NEER) and interest rate to assess the effects of commodity price changes on domestic inflation in the CEMAC region.

It is also important to note that the data on the nominal effective exchange rate for some countries (the Republic of Congo and Chad) in the region are not available in our database, we have decided to construct those data using bilateral nominal exchange with trading partners and the consumer price indices. Trading partners considered are: the United States, Japan, France, Germany, Italy, Belgium, Netherland, Spain, Portugal, the United Kingdom, Canada and China. Trade weights to these different countries are calculated as the total trade (exports and imports) with the weights calculated as simple average commercial exchanges over the period 2001-2005 with 2000 as base year reference. The formula is given as follows:

$$
\operatorname{TCEN}_{j}=\prod_{i=1}^{m} E_{i, j}^{w_{i, j}}
$$

$T C E N_{j}$ is the nominal effective exchange rate of the country $j, E$ is the bilateral nominal exchange rate between the country $j$ and $i$ expressed in foreign currency and $w_{i, j}$ is the country $i$ trade weight in the country $j$ trade. The number of trading partners is fixed at 12 countries. Based on this definition, an increase in NEER is considered as a currency appreciation.

\subsection{Empirical Model}

The econometric model applied in this analysis is that of panel cointegration. Given the heterogeneity of member states in the CEMAC zone and the existence of a common monetary policy, we adopt a methodology that takes into account the fixed effects and a possible cointegrating relationship between the variables in the regression model. The appropriate model is the one developed by Pesaran et al. (1997). It shares the same features with the 
panel error correction model in the sense that it takes into account dynamics of the short run and long run with the estimation carries out by a maximum likelihood. The model can be written as follows:

$$
\Delta L C P I_{i t}=\gamma_{i}\left(L C P I_{i t-1}+\beta_{i}^{\prime} X_{i t}\right)+\sum_{j=1}^{m-1} \alpha_{i j} \Delta L C P I_{i t-j}+\sum_{j=0}^{n-1} \lambda_{i j}^{\prime} \Delta X_{i t-j}+\mu_{i}+\varepsilon_{i t}
$$

$L C P I_{i t}$ is the natural logarithm of the consumer price index in country $i$ at $t, X_{i t}$ is the vector of independent variables such as the nominal effective exchange rate (NEER), the broad money supply (M2), the interest rate and the overall commodity price indices for the first analysis and the various sub-indices for the second analysis. $\gamma_{i}$ is the coefficient of error correction, $\beta_{i}^{\prime}$ is the vector of parameters of the independent variables over the long-term, $\lambda_{i j}^{\prime}$ vector of parameters of independent variables in the short run equation, $\mu_{i}$ the fixed effects and $\varepsilon_{i t}$ the error term. This model is a regression model with autoregressive distributed lag (ARDL), the choice of optimal number of lags is done using the information criterion AIC. PMG estimator (Pooled Mean Group), MG (Mean Group) and DFE (Dynamic Fixed Effects) are considered in this analysis with the emphasis on pooled mean group estimator.

As it is common with the time series analysis, panel unit root and cointegration tests are also discussed in this study to assess the long-term and short-term relationship between the consumer price indices of countries in the CEMAC zone and traditional determinants of inflation with a particular emphasis on food and oil prices. The panel unit root tests applied in this study are those developed by Im et al. (2003), Hadri (2000) and Breitung (2000). Panel unit root tests developed by Im et al. (2003) and Breitung are merely an extension the Augmented Dickey-Fuller (ADF) to panel data while Hadri (2000) test is an extension of the KPSS test to panel data (Baltagi, 2005).

Panel cointegration tests are numerous in the econometric literature: Kao (1999), McCoskey and Kao (1998), Pedroni (1999) and Larsson et al. (2000) among others. In this analysis we apply Pedroni (1999) test that takes into account the heterogeneity of countries in the region. Indeed, this cointegration test is designed for a multiple regression model, the number of cointegrating vector may vary among cross-section and finally this model ensures the heterogeneity of cross-section in the panel (Asteriou \& Hall, 2007).

\subsection{Empirical Results}

In this section, we present the empirical results of panel unit root and cointegration tests. The regression model of the relationship between commodity prices and inflation dynamic in the CEMAC zone will be carried out at the end of the section.

The table above shows the various the results of panel unit root tests. Results of IPS test, Breitung and Hadri tests are presented for the series at level and first difference. Overall, the null hypothesis cannot be rejected for the series at level except interest rates and food prices (LFOOD) that are stationary at 5\% for IPS test. However, the last two tests (Breitung and Hadri) cannot reject the null hypothesis of unit root for all variables at level. Despite these mixed results for the first test, we may conclude under that variables are I(1), which means series have to be differentiated to become stationary. Results on variables in first differences confirm this conclusion.

Table 1. Tests de racine unitaire sur données de panel

\begin{tabular}{lcccccc}
\hline & & LEVEL & & \multicolumn{3}{c}{ FIRST DIFFERENCE } \\
\hline & IPS & Breitung & Hadri & IPS & Breitung & Hadri \\
\hline LCPI & W-stat & T-stat & Z-stat & W-stat & T-stat & Z-stat \\
LM2 & 3.86329 & 1.26944 & 3.34959 & -23.8266 & -11.6995 & -0.83078 \\
LNEER & 0.25047 & -0.80533 & 8.12331 & -29.9511 & -15.2857 & 0.61051 \\
LIG & -0.88554 & -1.29557 & 4.66769 & -18.8336 & -2.5853 & 2.57081 \\
R & 0.43456 & 6.96218 & 7.81927 & -10.2807 & -4.83251 & 3.7077 \\
LFOOD & $-3.17561^{* * *}$ & 8.67024 & 4.96 & -17.264 & 5.47465 & -1.30499 \\
LMETAL & $-1.77369 * *$ & 2.78298 & 7.10063 & -11.5868 & -8.28301 & -0.54214 \\
LOIL & 3.17258 & 7.37302 & 7.19824 & -12.2394 & -6.14542 & 0.8354 \\
\hline
\end{tabular}

Note. $* * *, * * *$ significance at $1 \%, 5 \%$ and $10 \%$, respectively.

Cointegration test confirm the existence of a long run relationship between the variables in the model, as shown in the table below. Pedroni (1999) cointegration test is divided into two groups: the first group of four statistics 
(panel v-stat, panel rho-stat panel pp-stat and panel adf-stat) which capture the effects of within dimension while the second group has three statistics (group rho-stat, group pp-stat and group adf-stat) capture the effects of between dimension (Asterio \& Hall, 2007).

The results of cointegration test for the first model show that there is a long run relationship between consumer price index, the nominal effective exchange rate, money supply, interest rate and the commodity price index. With the exception of panel adf-stat and group adf-stat, the null hypothesis of no cointegration is rejected for other statistics.

However, all the test statistics for the second model reject the null hypothesis of no cointegration at 5\% significance level. Indeed, the decision on the Pedroni (1999) cointegration test is taken with respect to the critical value of each statistics. Critical values of $1 \%, 5 \%$ and $10 \%$ are constructed with asymptotic distribution of the mean and variance proposed by Pedroni (1999). For panel v-stat, we reject the null hypothesis for very large positive values of the test statistic whereas the null hypothesis is rejected for large negative values of other statistics.

Table 2. Panel cointégration test

\begin{tabular}{lcc}
\hline & MODEL1 & MODEL2 \\
\hline panel v-stat & $2.0414^{* *}$ & $1.99456^{* *}$ \\
panel rho-stat & $-2.99455^{* *}$ & $-2.34379^{* *}$ \\
panel pp-stat & $-3.05876^{* * *}$ & $-2.97614^{* * *}$ \\
panel adf-stat & -1.44263 & $-1.94904^{*}$ \\
group rho-stat & $-2.4413^{* *}$ & $-1.76091^{*}$ \\
group pp-stat & $-3.1268^{* * *}$ & $-2.91284^{* * *}$ \\
group adf-stat & -1.47586 & $-1.81762^{*}$ \\
\hline
\end{tabular}

Note. $* * *, * *, *$ significance at $1 \%, 5 \%$ et $10 \%$.

Once long-run relationship is found for different regression models, it is therefore important to estimate the dynamic model between domestic inflation and commodity prices in the CEMAC region to isolate the long-term effects from the short-term effects. We apply Pooled mean group estimator (PMG) to carry out the model regression. Table below shows the results for the different models.

Results of the three different models are presented in the table. The first model estimates relationship between domestic consumer price index, commodity price index and traditional determinants of inflation such as money supply, nominal effective exchange rate and interest rate. The second model breaks down the overall commodity price index in sub-index of foods, metals and oil in the regression model. Finally, the third model takes into account the effects of nominal exchange rate appreciation on the inflation dynamic in the region.

In addition, the regression model considered highlights the dynamic inflation in the CEMAC region over the long and the short run. The coefficient of the error correction term is particularly useful for the analysis of the dynamic inflation. Indeed, the coefficient of error correction term measures the speed of adjustment for any specific shock which may occur over time.

The results of model 1 show that there is a long-term relationship between the general consumer price index, money supply, nominal effective exchange rate, interest rate and the commodity price index. Despite the fact that money supply is not statistically significant, the rest of explanatory are statistically significant. Domestic inflation in the region can be explained by the nominal effective exchange rate, interest and commodity price index. An appreciation of nominal effective exchange rate by $1 \%$ is accompanied by a decreasing consumer price by $0.69 \%$ while an increase in the interest rate by $1 \%$ contributes to a reduction in the general price level of $0.051 \%$. The money supply, although having the expected sign, is not statistically significant. The overall commodity price index is positively related to the consumer price index of the CEMAC region. A surge of commodity price index by $1 \%$ leads to an increase of the consumer price index of the region by $0.22 \%$. These results are only valid for the long run analysis. However, inflation in the CEMAC can be better explained over the short-run since the coefficients of the regression are not statistically significant.

A breaking down the overall commodity price index in sub-component of foods, metals and oil products, the regression model 2 shows how important are these sub-indices in the of inflation dynamic of the region. Traditional determinants of inflation (monetary, exchange rate and nominal interest rate) are statistically significant with the expected signs. Particular attention is paid to the effects of the various sub-indices on the general price level. Food and oil prices are positively related to the consumer price index of the CEMAC zone. 
Indeed, an increase by $1 \%$ of food and oil prices contributes to the rising of consumer price by $0.19 \%$ and $0.11 \%$, respectively. The metal price sub-index, although statistically significant, does not have an expected sign. However, the results of the short-term dynamics are not statistically significant, the error correction term is statistically significant.

Given the fixed parity between CFA franc and Euro, domestic inflation seems to be cautioned by the strong Euro. The role exchange rate regime is taken into account in the third model by interaction between nominal effective exchange rate and commodity price index. We find the exchange rate regime to a significant contributor of the domestic inflation in the zone. The pass-through of rising commodity prices is cautioned with an appreciation of the nominal exchange rate. Therefore, the cumulative effect of rising commodity prices on consumer price index is negative. As a result, appreciation of the nominal effective exchange rate during the 2007-2008 has contributed to reduce the effects of rising food and oil prices on domestic inflation in the CEMAC region. Parity fixed between CFA Franc and the strong Euro has significantly contributed to control domestic inflation rather an implement of prudent monetary policy.

Table 3. Results of PMG estimation

\begin{tabular}{|c|c|c|c|c|c|c|}
\hline & MODEL1 & & MODEL2 & & MODEL3 & \\
\hline variables & Coefficient & T-stat & coefficient & T-stat & Coefficient & T-stat \\
\hline \multicolumn{7}{|c|}{ LONG-RUN EQUATION } \\
\hline lneer & -0.0958 & -0.77 & $-0.36027 * *$ & -2.21 & -0.18979 & -1.48 \\
\hline $\operatorname{lm} 2$ & $0.11792^{* * *}$ & 5.09 & 0.00041 & 0.02 & $0.11625^{* * *}$ & 5.05 \\
\hline lig & $0.09848 * * *$ & 5.01 & & & & \\
\hline $\mathrm{r}$ & 0.00452 & 0.36 & -0.02079 & -1.30 & .00322 & 0.26 \\
\hline lfood & & & $0.18346^{* * *}$ & 7.27 & & \\
\hline lmetal & & & 0.00457 & 0.18 & & \\
\hline loil & & & $0.06523^{* *}$ & 2.94 & & \\
\hline Lig*Ineer & & & & & $0.02119^{* * *}$ & 5.07 \\
\hline \multicolumn{7}{|c|}{ SHORT-RUN EQUATION } \\
\hline ect & $-0.13297 * * *$ & -4.12 & $-0.15019 * *$ & -2.68 & $-0.13382 * * *$ & -4.11 \\
\hline D.lneer & -0.24695 & -1.61 & -0.19147 & -1.19 & $-0.28993 *$ & -1.73 \\
\hline D. $\operatorname{lm} 2$ & $0.07534 *$ & 2.58 & $0.06930^{* * *}$ & 2.18 & $0.07547 * *$ & 2.61 \\
\hline D.lig & 0.04658 & 1.23 & & & & \\
\hline D.r & $-0.05207^{* *}$ & -3.38 & $-0.04682 * *$ & -3.04 & $-0.05196^{* *}$ & -3.38 \\
\hline D.LFOOD & & & $0.02600^{*}$ & 1.95 & & \\
\hline D.LMETAL & & & 0.00707 & 0.28 & & \\
\hline D.LOIL & & & -0.01497 & -0.69 & & \\
\hline Lig*Ineer & & & & & 0.00952 & 1.20 \\
\hline const & $0.51220^{* * *}$ & 4.16 & $0.78485^{* *}$ & 2.68 & $0.57626^{* * *}$ & 4.15 \\
\hline No. observations & \multicolumn{2}{|c|}{835} & \multicolumn{2}{|c|}{835} & \multicolumn{2}{|c|}{835} \\
\hline No. countries & \multicolumn{2}{|c|}{5} & \multicolumn{2}{|c|}{5} & \multicolumn{2}{|c|}{5} \\
\hline LOGL & \multicolumn{2}{|c|}{2334.418} & \multicolumn{2}{|c|}{2371.837} & \multicolumn{2}{|c|}{2334.608} \\
\hline
\end{tabular}

Note. $* * *, * *$, significance at $1 \%, 5 \%$ and $10 \%$, respectively.

The results of Models 1 and 2 are quite similar for the traditional determinants of domestic inflation. This means that the decomposition of the overall index in sub-indices did not affect the impact of traditional determinants of domestic inflation dynamics in the region. Similarly, the coefficient error correction terms for the three models are relatively similar. It is important to point out that on average $8.5 \%$ of the shocks occurred during a year are corrected over the next year.

\section{Conclusion and Policy Implications}

The recent food crisis of 2008, with the steady rise of oil prices due to strong demand from emerging economies, did not occurred without effects on the domestic inflation in the CEMAC region. Indeed, member states of this monetary union are mostly oil exporters with a fixed parity between their currency and Euro. In addition, countries of the union are in majority low income whose generally spend about half of their income on food items. In light of these characteristics, it is important to assess the issues of rising commodity prices on domestic inflation of the region.

It should be remembered that the consumer price index in the CEMAC zone crossed the symbolic threshold of $3 \%$ 
while remaining below $10 \%$ compared to the average rate in sub-Saharan Africa economies which was $11.7 \%$. This shows that consumer price index of the region has been as a result of soaring commodity prices though somehow contained. The study seeks to address the question whether a rise in commodity prices, particularly food and oil prices, did affect the dynamic of domestic inflation CEMAC zone. If this question is answered positively, what would explain the low pass-through from commodity price changes to the inflation dynamic in the union?

To answer the research question of the study, an empirical analysis of the relationship between domestic inflation and commodity price index through the technique of panel cointegration. This methodology is interesting insofar as it simultaneously treats the effects of the dynamics of long-term and short-term with an emphasis on the speed of adjustment to shocks. This econometric technique takes into account in the regression model heterogeneity of member states in the CEMAC zone.

The overall results show that all the transformed series applying natural logarithm are non-stationary and that there is a cointegration relationship between consumer price index, nominal effective exchange rate, money supply and the commodity price index as well as the different sub-indices. This result is consistent with the literature which found that there is a cointegration relationship between consumer price index and commodity prices.

In summary, the overall results show that an appreciation of the nominal effective exchange rate and a rising interest rate have a reducing effect on the consumer price index of the region whereas excessive money supply and commodity price changes are potential source of inflation in the zone. This result is only valid over the long-term relationship since the coefficients of the short-run analysis are not statistically significant. We may conclude that rising price of commodities translate to consumer price index of the region with some delays. Hence, it is important for monetary authorities to remain vigilant during the commodity prices surge.

In addition, a much more detailed analysis with the overall index disaggregated into sub-index of food, metals and oil, shows that the food and oil sub-indices are positively related to the domestic inflation of the zone. Despite the low pass-through from these sub-indices to inflation in the area, the food sub-index has a greater impact. The low pass-through could be explained by price control through subsidies as well as parity fixed against the strong Euro.

As economic policy recommendations, we suggest commodity prices, particularly food and oil prices to be taken into account in the forecasting exercises of domestic inflation in the CEMAC zone. Monetary authorities should strengthen their tools of monetary policy to fight against inflation while a coordinated policy of domestic supply of food products that are heavily imported such as rice and wheat should be implemented in the area in order to reduce harmful effects of rising commodity prices from international markets due to exogenous shocks (climate change, bad harvest, bio-fuel, financialization of commodities).

In light of the theoretical literature on the sources of inflation, we can conclude that the structuralist view of the sources of inflation is verified in the CEMAC zone. But the CFA franc peg to euro plays a stabilizing role in the dynamics of imported inflation in the area. The stabilizing role of the CFA Franc peg to Euro appears to mask the role of the price control on imported inflation, especially from oil and food prices in the region and vice-versa. Hence, the importance of a more thorough study to isolate the roles of fixed parity between CFA franc and Euro, subsidies and monetary policy in the dynamics of inflation in the CEMAC zone.

\section{References}

Adams, G. F., \& Ichino, Y. (1995). Commodity prices and inflation: A forward-looking price model. Journal of Policy Modeling, 17(4), 397-426. https://doi.org/10.1016/0161-8938(95)00017-N

AFDB. (2011). Inflation dynamics in selected East African countries: Ethiopia, Kenya, Tanzania and Uganda. African Development Bank (AFDB).

Agénor, \& Montiel. (2008). Development macroeconomics (3rd ed.). Princeton university press.

Al-Eyd, A., Amaglobeli, D., Sukurov, B., \& Sumlinski, M. (2012). Global food price inflation and policy response in Central Asia. IMF working paper 12/86, Washington, DC. https://doi.org/10.5089/9781475502497.001

Asteriou, D., \& Hall, S. (2007). Applied Econometrics: A modern approach. New York: Palgrave Macmillan.

Baffes, J. (2007). Oil spills on other commodities. Resources Policy, 32, 126-134. https://doi.org/10.1016/j.resourpol.2007.08.004

Bloomberg, B. S., \& Harris, E. S. (1995). The commodity-consumer price connection: Fact or fable? FRBNY 
Economic Policy Review, October 1995.

Boughton, \& Branson. (1988). Commodity prices as leading indicator of inflation. National Bureau of Economic Research Paper Series, 2750, Cambridge, USA. https://doi.org/10.3386/w2750

Browne, F., \& Cronin, D. (2010). Commodity prices, money and inflation. Journal of Economics and Business, 62, 331-345. https://doi.org/10.1016/j.jeconbus.2010.02.003

Ciner, C. (2011). Commodity prices and inflation: Testing in the frequency domain. Research in International Business and Finance, 25, 229-237. https://doi.org/10.1016/j.ribaf.2011.02.001

Deaton, A., \& Miller, R. (1995). International commodity prices, macroeconomic performance, and politics in Sub-Saharan Africa. Princeton studies in International Finance, 79.

Dehn, J. (2000). Commodity price uncertainty and shocks: Implications for economic growth. Center for the Study of African Economies, WPS/200-10.

Egert, B. (2011). Catching-up and inflation in Europe: Balassa-Samuelson, Engle's law and other culprits. Economic Systems, 35, 208-229. https://doi.org/10.1016/j.ecosys.2010.06.001

Flood, R. (1989). Commodity prices and aggregate inflation: Would a commodity price be worthwhile? Canergie-Rochester Conference Series on Public Policy, 31, 241-246. https://doi.org/10.1016/0167-2231(89)90012-2

Furlong, F., \& Igenito, R. (1996). Commodity prices and inflation. FRBSF Economic Review, 2, 27-47.

Hobijn, B. (2008). Commodity price movements and PCE inflation. Current Issues in Economics and Finance, FRBNY, 14(8).

IMF. (2012). Managing global growth risks and commodity price shocks: Vulnerabilities and policy challenges for low-income countries. International Monetary Fund, washington DC. https://doi.org/10.5089/9781498339766.007

Jongwanich, J., \& Park, D. (2009). Inflation in developing Asia. Journal of Asian Economics, 20, 507-518. https://doi.org/10.1016/j.asieco.2009.07.004

Kao, C. (1999). Spurious regression and residual-based tests for cointegration in panel data. Journal of Econometric, 90, 1-44. https://doi.org/10.1016/S0304-4076(98)00023-2

Kao, C., \& Chiang, M. H. (2000). On the estimation and inference of a cointegrated regression in panel data. Advances in Econometrics, 15, 179-222. https://doi.org/10.1016/S0731-9053(00)15007-8

Krugler, P. (1991). Common trends, commodity prices and consumer prices. Economics Letters, 37, 345-349. https://doi.org/10.1016/0165-1765(91)90069-W

McCoskey, S., \& Kao, C. (1998). A residual-based test of the null of cointegration in panel data. Econometric Reviews, 17, 57-84. https://doi.org/10.1080/07474939808800403

Nazlioglu, S., \& Soytas, U. (2012). Oil price, agricultural commodity prices, and the dollar: A panel cointegration and causality analysis. Energy Economics, 34, 1098-1104. https://doi.org/10.1016/j.eneco.2011.09.008

Pedroni, P. (1999). Critical values for cointegration tests in heterogeneous panels with multiple regressors. Oxford Bulletin of Economics and Statistics, 61, 653-678. https://doi.org/10.1111/1468-0084.61.s1.14

Pesaran, M. H., Shin, Y., \& Smith, R. P. (1999). Pooled mean group estimation of dynamic heterogeneous panels. Journal of American Statistical Association, 94, 621-634. https://doi.org/10.1080/01621459.1999.10474156

Zhou, S., \& Mahdavi, S. (1997). Gold and commodity prices as leading indicators of inflation: Tests of long-run relationship and predictive performance. Journal of Economics and Business, 49, 475-489. https://doi.org/10.1016/S0148-6195(97)00034-9

Zoli, E. (2009). Commodity price volatility, cyclical fluctuations and convergence: What is ahead for inflation in emerging Europe? IMF working paper 09/41, Washington, DC. https://doi.org/10.5089/9781451871890.001

\section{Notes}

Note 1. WAEMU: West African Economic and Monetary Union; CAEMC: Central African Economic and Monetary Community

Note 2. See Agenor and Montiel (2008). 


\section{Appendix}

\section{Appendix 1. commodity prices}

Table 1 . commodity price changes $(\%)$

\begin{tabular}{ccccc}
\hline & $2001-2006$ & 2007 & 2008 & 2009 \\
\hline Total commodity price index & 12.07 & 11.81 & 27.56 & -30.05 \\
Non-fuel price index & 7.93 & 14.05 & 7.51 & -15.85 \\
Fuel price index & 15.53 & 10.45 & 40.08 & -36.85 \\
Food price index & 5.23 & 15.22 & 23.35 & -14.67 \\
Metals price index & 18.54 & 17.36 & -7.83 & -19.67 \\
Wheat price index & 9.51 & 33.11 & 27.72 & -31.45 \\
Maize price index & 6.03 & 34.27 & 36.74 & -25.85 \\
Rice price index & 7.60 & 9.51 & 110.65 & -15.83 \\
Sugar price index & 9.44 & -23.20 & 14.63 & 30.19 \\
\hline
\end{tabular}

Source: WEO and author's calculation.

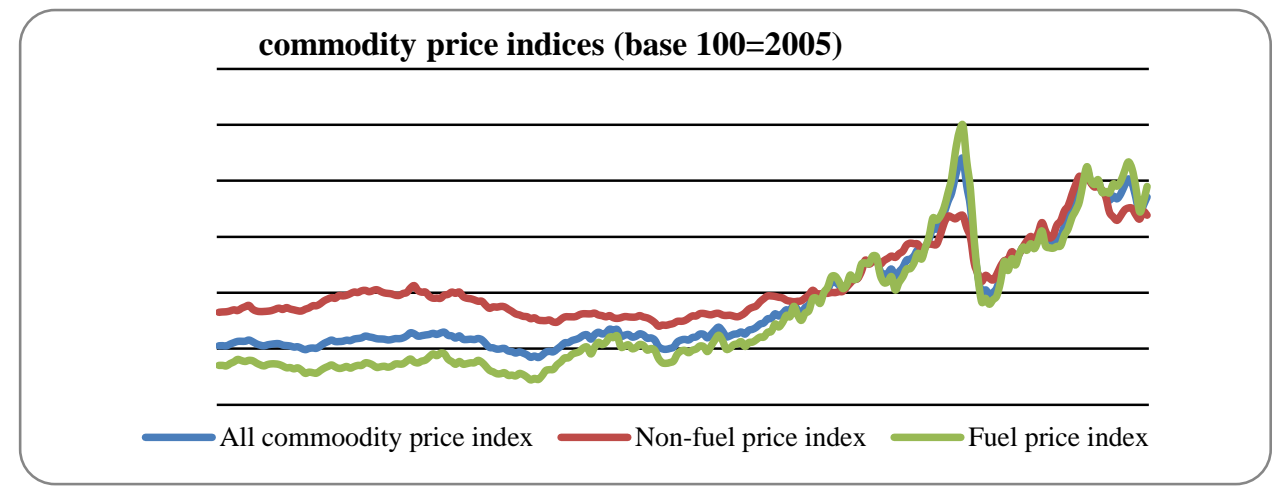

Source: IMF World Economic Outlook.

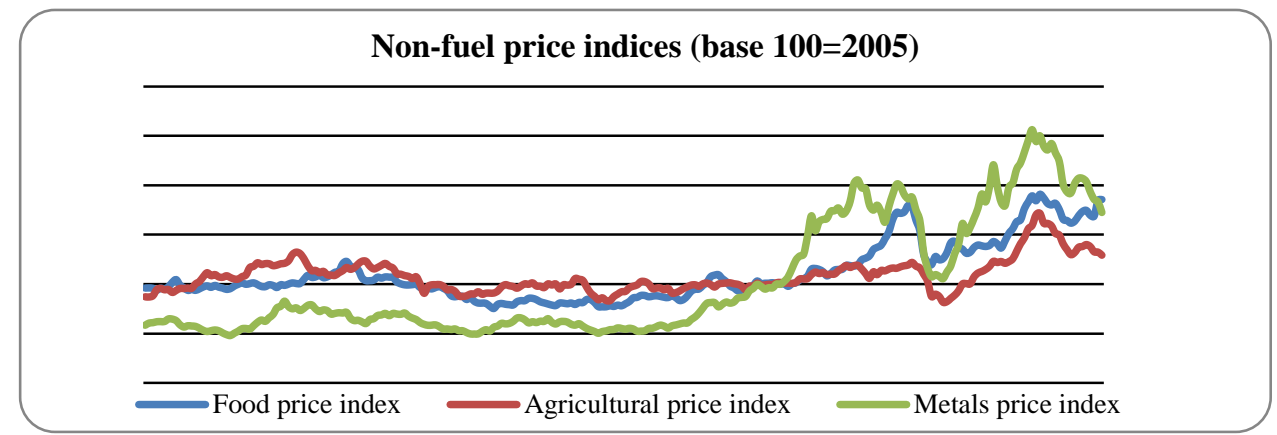

Source: IMF World Economic Outlook.

\section{Appendix 2. Distribution of food and metal items in the CEMAC region}

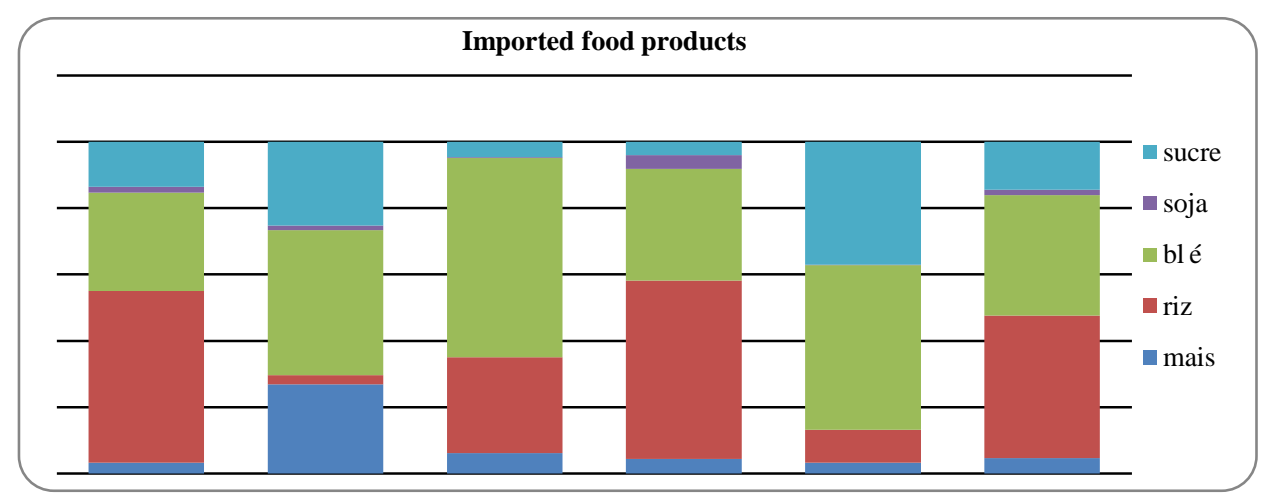

Source: author's calculation and UNCOMTRADE. 


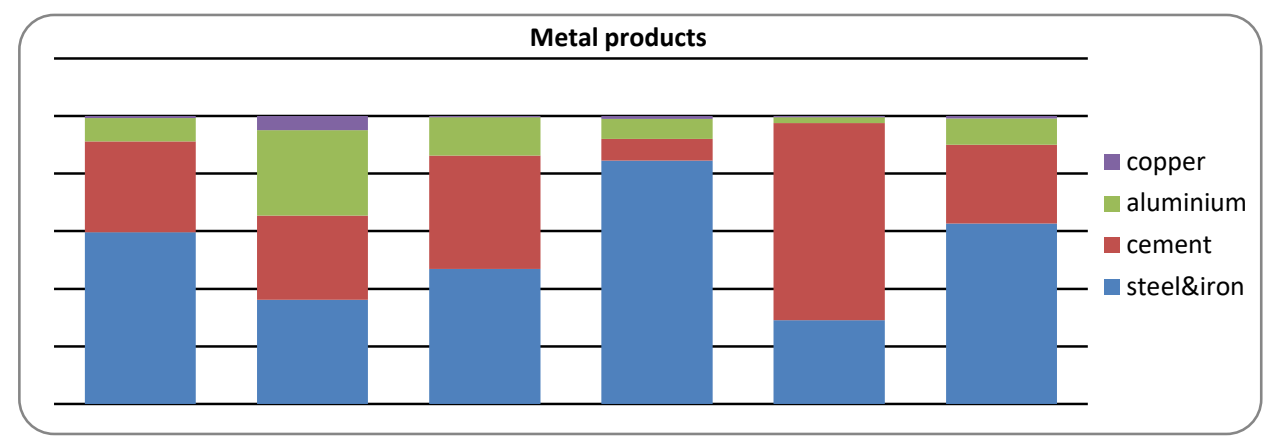

Source: author's calculation and UNCOMTRADE.

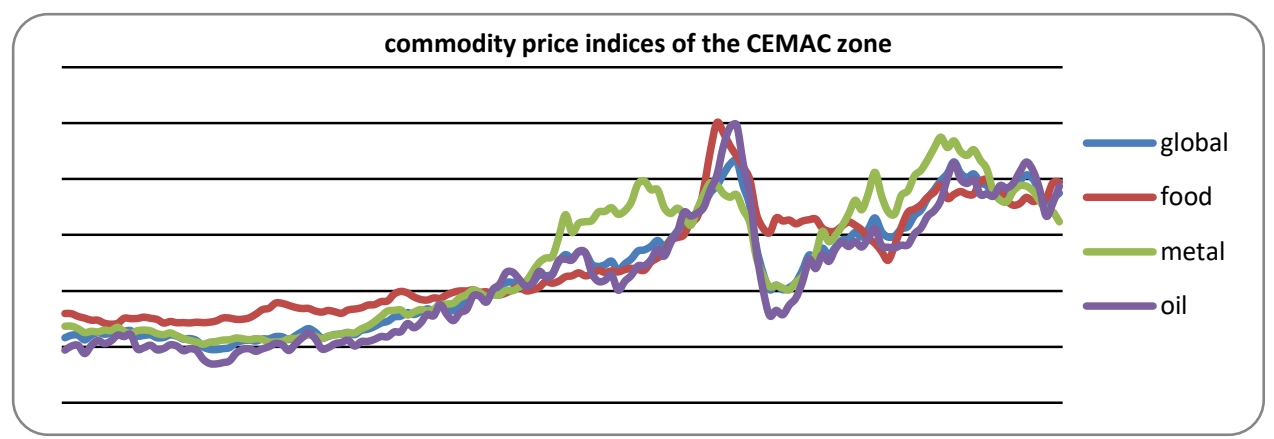

Source: author's calculation and UNCOMTRADE.

\section{Appendix 3. Economic indicators of the CEMAC region}

Table 1. Economic indicators of CEMAC

\begin{tabular}{lcccc}
\hline & $2000-2005$ & 2006 & 2007 & 2008 \\
\hline Growth rate (\%) & 4.9 & 3.1 & 4.7 & 4.0 \\
Inflation rate (\%) & 2.1 & 5.4 & 1.8 & 5.9 \\
M2 growth rate (\%) & 11.7 & 19.2 & 12.4 & 19.3 \\
Investment (\%GDP) & 30.0 & 27.1 & 29.6 & 28.1 \\
Fiscal account (\%GDP) & 7.3 & 12.6 & 10.2 & 13.3 \\
Current account (\%GDP) & -2.6 & 3.3 & 0.1 & 4.6 \\
Population (millions) & 32.8 & 36.5 & 37.5 & 38.4 \\
\hline
\end{tabular}

Source: BEAC.

Table 2. Economic indicators of Cameroon

\begin{tabular}{lcccc}
\hline & $2000-2005$ & 2006 & 2007 & 2008 \\
\hline Growth rate & 4.0 & 3.2 & 4.0 & 3.7 \\
Inflation rate & 1.9 & 5.1 & 1.1 & 5.3 \\
M2 growth rate & 9.7 & 9.1 & 15.2 & 13.9 \\
Investment (\%GDP) & 27.9 & 25.4 & 27.0 & 26.3 \\
Fiscal account (\%GDP) & 6.0 & 6.9 & 5.7 & 4.8 \\
Current account (\%GDP) & -5.2 & -1.3 & -1.2 & -3.4 \\
Population (millions) & 16.1 & 17.6 & 18.1 & 18.5 \\
\hline
\end{tabular}

Source: BEAC.

Table 3. Economic indicators of the Republic of Congo

\begin{tabular}{lcccc}
\hline & $2000-2005$ & 2006 & 2007 & 2008 \\
\hline Growth rate (\%) & 4.6 & 7.0 & -2.5 & 5.2 \\
Inflation rate (\%) & 1.5 & 4.7 & 2.5 & 5.3 \\
M2 growth rate (\%) & 16.4 & 48.4 & 7.1 & 36.7 \\
Investment (\%GDP) & 28.0 & 40.1 & 53.7 & 42.9 \\
Fiscal account (\%GDP) & 9.4 & 22.4 & 13.0 & 30.7 \\
Current account (\%GDP) & 11.2 & 1.7 & -18.7 & -0.9 \\
Population (millions) & 3.2 & 3.5 & 3.6 & 3.7 \\
\hline
\end{tabular}

Source: BEAC. 
Table 4. Economic indicators of Gabon

\begin{tabular}{|c|c|c|c|c|}
\hline & $2000-2005$ & 2006 & 2007 & 2008 \\
\hline Growth rate $(\%)$ & 1.2 & 1.3 & 5.1 & 2.0 \\
\hline Inflation rate $(\%)$ & 0.9 & 4.0 & 4.8 & 5.3 \\
\hline M2 growth rate $(\%)$ & 11.2 & 17.2 & 6.9 & 8.9 \\
\hline Investment (\%GDP) & 25.4 & 23.0 & 22.6 & 21.6 \\
\hline Fiscal account (\%GDP) & 12.3 & 12.2 & 11.5 & 13.9 \\
\hline Current account (\%GDP) & 12.2 & 17.0 & 17.6 & 23.0 \\
\hline Population (millions) & 1.4 & 1.57 & 1.62 & 1.68 \\
\hline
\end{tabular}

Source: BEAC.

Table 5. Economic indicators of Equatorial Guinea

\begin{tabular}{lcccc}
\hline & $2000-2005$ & 2006 & 2007 & 2008 \\
\hline Growth rate (\%) & 26.2 & 5.3 & 23.2 & 15.2 \\
Inflation rate (\%) & 6.3 & 5.0 & 5.5 & 6.0 \\
M2 growth rate (\%) & 42.0 & 14.1 & 41.3 & 30.1 \\
Investment (\%GDP) & 42.8 & 27.0 & 31.1 & 30.5 \\
Fiscal account(\%GDP) & 14.1 & 25.8 & 21.0 & 20.7 \\
Current account (\%GDP) & -9.6 & 9.1 & 1.1 & 6.4 \\
Population (thousands) & 1125.5 & 1383.0 & 1446.0 & 1508.0 \\
\hline
\end{tabular}

Source: BEAC.

Table 6. Economic indicators of Central African Republic

\begin{tabular}{lcccc}
\hline & $2000-2005$ & 2006 & 2007 & 2008 \\
\hline Growth rate (\%) & 1.0 & 4.3 & 3.6 & 2.0 \\
Inflation rate (\%) & 2.4 & 6.6 & 1.0 & 9.3 \\
M2 growth rate (\%) & 3.3 & -4.2 & -3.7 & 16.5 \\
Investment (\%GDP) & 8.7 & 8.8 & 8.1 & 9.8 \\
Fiscal account(\%GDP) & 2.1 & 4.5 & 3.4 & 4.2 \\
Current account (\%GDP) & -2.4 & -3.1 & -6.1 & -9.3 \\
Population (millions) & 3.8 & 4.2 & 4.3 & 4.4 \\
\hline
\end{tabular}

Source: BEAC.

Table 7. Economic indicators of Chad

\begin{tabular}{lcccc}
\hline & $2000-2005$ & 2006 & 2007 & 2008 \\
\hline Growth rate & 12.7 & 0.8 & 1.7 & -1.4 \\
Inflation rate & 3.7 & 8.1 & -7.4 & 8.3 \\
M2 growth rate & 16.2 & 51.8 & 2.5 & 28.4 \\
Investment (\%GDP) & 50.0 & 25.8 & 25.9 & 26.6 \\
Primary fiscal deficit (\% GDP) & -0.4 & 4.2 & 4.2 & 5.2 \\
Current account (\%GDP) & -35.8 & 5.7 & -4.2 & 3.0 \\
Population (millions) & 7.6 & 8.28 & 8.47 & 8.67 \\
\hline
\end{tabular}

Source: BEAC.

\section{Copyrights}

Copyright for this article is retained by the author(s), with first publication rights granted to the journal.

This is an open-access article distributed under the terms and conditions of the Creative Commons Attribution license (http://creativecommons.org/licenses/by/4.0/). 